\title{
Skeletochronology and isotopic analysis of a captive individual of Alligator mississippiensis Daudin, 1802
}

\author{
Nicole Klein ${ }^{*}, 1$, Torsten Scheyer ${ }^{2}$ and Thomas Tütken ${ }^{1}$ \\ ${ }^{1}$ Steinmann Institut für Geologie, Paläontologie und Mineralogie, Universität Bonn, Nussallee 8, 53115 Bonn, Germany. \\ E-mail: nklein@uni-bonn.de; tuetken@uni-bonn.de \\ ${ }^{2}$ Paläontologisches Institut und Museum, Universität Zürich, Karl Schmid-Straße 4, 8006 Zürich, Switzerland. \\ E-mail: tscheyer@pim.uzh.ch
}

Received 19 May 2008

Accepted 2 February 2009

Published 3 August 2009

\begin{abstract}
In the present study, bone histology and isotope composition $(\mathrm{C}, \mathrm{N}, \mathrm{O})$ of a femur and three postcranial osteoderms from an approximately 23-25 year-old captive female Alligator mississippiensis Daudin, 1802 were analyzed to infer the recorded life history. The number of visible annual growth marks in the femur cross-section is less than the known age for the individual concerned, this information clearly shows that skeletochronology has certain limits. However, bone histology reflects very well the traceable life history of this individual and its slow growth in early ontogeny. Bone histology on the basis of the osteoderms shows massive remodeling and an only incompletely preserved growth record, reflecting the egg-laying status of this individual. Interestingly, the carbon and especially the nitrogen isotope compositions of the osteoderms differ from those of the femur. This presumably reflects dietary changes and/or differences in resorption and remodeling processes during tissue formation of these bones. The $\mathrm{N}, \mathrm{C}$, and $\mathrm{O}$ isotope composition of the femur is consistent with the food and water the alligator had ingested during the last years of its life. Thus, contrary to the osteoderms, the femur yields reliable data for the reconstruction of an individual's dietary and environmental history.
\end{abstract}

\section{Introduction}

Skeletochronology, the estimation of individual age based on bone histological data, has been well established to determine the ontogenetic age of Recent and fossil vertebrates (e.g., Ricqlès 1968, 1976a, 1976b; Zug et al. 1986; Castanet et al. 1988, 1993; Castanet \& Smirina 1990; Castanet 1994; Horner et al. 1999, 2000; Steyer et al. 2004; Chinsamy 1990, 1993; ChinsamyTuran 2005; Erickson \& Tumanova 2000; Erickson et al. 2004; Erickson 2005; Klein \& Sander 2007; Sanchez et al. 2008). However, these techniques are sometimes difficult to use because of the influence of bone remodeling and bone plasticity, and the sometimes irregular appearance of growth marks (Klein \& Sander 2008). Additionally, the trigger for the deposition of lines of arrested growth (LAGs) is not entirely understood yet (see discussion in e.g., Starck \& Chinsamy 2002; Chinsamy \& Hillenius 2004; Padian \& Horner 2004; Bybee et al. 2006; Lee \& Werning 2008). Simi- larly, the strictly yearly periodicity of LAGs is questionable, because at least juveniles of tropical turtles and crocodilians seem to miss sometimes deposition of annual LAGs in their early life stage (e.g., Björndal et al. 1998; Padian et al. 2004). Other causes, such as disease, can lead to the deposition of two or even more LAGs per year (Buffrénil \& Castanet 2000).

Life conditions and effects on growth are clearly different in captive individuals and the use of skeletochronology is problematic here (Buffrénil 1980a; Chinsamy \& Hillenius 2004; Padian \& Horner 2004). However, these animals can show the variability but also the constraints of growth rates and bone tissue types in a group. Thus, they yield important information for the understanding of growth and the origin and formation of bone tissues. Because of the availability of more and regular food, combined with less activity and a more constant (warm) climate, crocodilians kept in captivity usually grow much faster than those in the wild (Buffrénil 1980b). A histological sample of a captive crocodilian,

\footnotetext{
* Corresponding author
} 
which was kept in its early ontogeny under insufficient exogenous conditions has as yet not been studied.

Enlow \& Brown (1957) were among the first who described long bone and osteoderm histology of extant and fossil crocodilians. Peabody (1961) described lamellar-zonal bone tissue and growth marks in various bones of different taxa. He hypothesized that fast-growing crocodilians do not necessarily deposit annual growth marks (Peabody 1961). Ricqlès (1976b) mentioned a zonal pattern in crocodilian long bones with each zone containing longitudinal primary vascular canals. He observed that the bone tissue between the vascular canals sometimes consists of parallel-fibred or even woven bone (Ricqlès 1976b). Buffrénil (1980a, 1980b) studied cyclical growth in wild and captive Crocodylus siamensis Schneider, 1801 and other species of living and fossil crocodilians. He found a clear discrepancy in growth rate of wild and captive crocodilians but in both, a general good correlation between the number of growth rings and individual age (Buffrénil 1980a, 1980b). Furthermore, also captive crocodilians, which were kept in a constant environment, exhibit cyclical growth (Buffrénil 1980a).

Hutton (1986) and later Tucker (1997) estimated the age of wild crocodilians from the skeletochronology of growth marks in osteoderms. Both pointed out that osteoderms of egg-laying females are not well suited for skeletochronology because of the high amount of remodeling in osteoderms and their possible function as calcium storage during oogenesis (Hutton 1986; Tucker 1997). A detailed histological description of an ontogenetic series of Alligator mississipiensis Daudin, $1802 \mathrm{fe}-$ mora was given by Lee (2004). He detected a predominance of longitudinally orientated vascular canals and collagen fibres throughout growth (Lee 2004). Several recent studies refer to crocodilian bone microstructure, often in comparison with extinct vertebrate bones (e.g., Ricqlès et al. 2003; Padian et al. 2004; Lee \& Werning 2008). Reid (1984, 1997), Chinsamy \& Hillenius (2004) and Turmarkin-Deratzian (2007) described fibro-lamellar bone in wild crocodilians, demonstrating that this bone type, which is usually found in dinosaurs, birds and large mammals, is indeed rather rare in crocodilians but can occasionally occur. This is an important observation, which contributes to the discussion if fibro-lamellar bone is possibly plesiomorphic in archosaurs (Ricqlès et al. 2008).

Long bones generally provide the best results for bone histological studies (Castanet et al. 1993; Chinsamy-Turan 2005; Erickson 2005) and dermal bones, e.g., osteoderms, have been used as well (Buffrénil \& Buffetaut 1981; Hutton 1986; Hua \& Buffrénil 1996; Tucker 1997; Scheyer \& Sander 2004; Hill \& Lucas 2006; Hayashi \& Carpenter 2007; Scheyer 2007; Scheyer \& Sánchez-Villagra 2007).

In addition to histological investigations, isotopic analysis of skeletal remains can also yield information about life history and tissue formation rates (e.g., Straight et al. 2004; Tütken et al. 2004), as well as about diet, climate, migration and thermophysiology (Fricke \& Rogers 2000; Stoskopf et al. 2001; Kohn \&
Cerling 2002; Amiot et al. 2006, 2007; Koch 2007). Few studies have analyzed the oxygen isotope composition of the skeletal apatite of crocodile bones and teeth (Stoskopf et al. 2001; Amiot et al. 2007) to infer their thermophysiology and body water composition. The study of Amiot et al. (2007) established an empirical calibration of the oxygen isotope composition between the ingested environmental water and enamel apatite for wild and farm-raised crocodiles, which can be used to infer drinking water compositions for crocodiles.

The aim of this study is to compare the skeletochronologic life history data for dermal and endoskeletal bone of an adult individual of Recent Alligatoridae of which the actual age is approximately known. The known data concerning the life history of the alligator are compared with the life history recorded in the bone histology. The almost known individual age serves as a reference for the age data estimated based on the bone histology, and may produce a more reliable application for fossil specimens. Finally, the carbon, nitrogen and oxygen isotope compositions of the different bone types were analyzed to determine whether they record similar values and thus reflect similar dietary and drinking water compositions.

\section{Materials}

The investigated skeletal remains were collected from a captive Alligator mississipiensis which died in 1989 or 1990. After maceration, it was stored in the collection of the Staatliches Museum für Naturkunde, Stuttgart, Germany, under the inventory number SMNS 10481 A cross-section from the mid-shaft region of the right femur (total femoral length $14.8 \mathrm{~cm}$ ), and three osteoderms from the dorsal trunk region were taken for bone histology and isotope analyses.

The osteoderms are isolated armor bones, whose natural position on the body of the animal was not recorded during maceration. The positions of the osteoderms can still be inferred, though, by their outer shapes. All three osteoderms exhibit a slight striation or crosshatch pattern on the marginal areas of the dorsal bone surfaces (mostly in the anterior parts of the osteoderms).

Traceable life history data of SMNS 10481. The following information is based on the personal communication (2008) with Ch. Wermuth, the daughter of Dr. Heinz Wermuth. The alligator was an egg-laying female with a total body length of $185 \mathrm{~cm}$. Since 1969 it lived as a pet with Dr. H. Wermuth (SMNS) in Ludwigsburg near Stuttgart, southern Germany. Before it went into the custody of Dr. H. Wermuth, it was kept in very poor conditions over an unknown period of time in a leisure park in Switzerland. At that time, the specimen was malnourished, unable to walk on its legs (rachitic), and had lost nearly all its teeth. However, it soon recovered under the optimized living conditions provided for it in Ludwigsburg, and it continued to grow and even began laying eggs. In Ludwigsburg its diet consisted mainly of teleosts and chicken. Nothing is known about the origin of the alligator specimen (i.e., if it was captive bred or caught in the wild). In 1969 , when it was relocated by Dr. H. Wermuth, it had a body length of around $100 \mathrm{~cm}$. According to several studies (Neill 1971; Jacobsen \& Kushlan 1989; Ross 2002) wild alligators reach a body length of around $100 \mathrm{~cm}$ within two to four years, whereas captive alligators can grow much faster (Neill 1971). However, we assume that specimen SMNS 10481 was at least three years old in 1969. Because of the described poor conditions in its early life, growth was presumably slower than in crocodilians which lived under normal conditions and individual SMNS 10481 may be slightly older. Thus, when it died in 1989 or 1990 it was at least 23 to 25 years old. 


\section{Methods}

Bone histology. For the microstructural analysis of the bones, three osteoderms and one femur of Alligator mississippiensis (SMNS 10481) were sampled. The femur was cut at its mid-shaft region where the most undisturbed growth record could be expected (e.g., Castanet et al. 1993; Sander 1999; Klein \& Sander 2007). The rectangular osteoderm was sampled in parasagittal and transverse planes, whereas the other two specimens were each sampled in transverse plane (Fig. 1). The bone histological terminology for the long bones largely follows FrancillonVieillot et al. (1990), that for the osteoderms Scheyer \& Sander (2004). Processing of the bones followed standard petrographic thin-sectioning techniques as applied in bone histology (Scheyer \& Sander 2004; Klein \& Sander 2007)

Prior to sectioning, the bone samples were embedded in synthetic resin (Araldite ${ }^{\circledR}$ 2020). Wet grinding and polishing of the bone sections to a thickness of about $60-80 \mu \mathrm{m}$ were done with $\mathrm{SiC}$ grinding powders ( $\mathrm{SiC} 600,800)$. Thin-sections were then studied with a Lei$\mathrm{ca}^{\mathrm{B}}$ DM 2500 compound polarizing microscope, equipped with a digital camera Leica ${ }^{\circledR}$ DFC 420C

$C$ and $O$ isotope measurements of the carbonate in the apatite. Carbon and oxygen of the carbonate bound in the bone apatite were analyzed. Isotopic analysis of the bone samples was done using $10 \mathrm{mg}$ of bone powder, which was chemically pretreated for three hours with $2 \% \mathrm{NaOCl}$ solution and five minutes in $0.1 \mathrm{M}$ suprapure acetic acid, to remove organics and adsorbed carbonate, respectively, prior to analysis of the carbon $\left(\delta^{13} \mathrm{C}\right)$ and oxygen $\left(\delta^{18} \mathrm{O}_{\mathrm{CO} 3}\right)$ isotopic composition of the structurally bound carbonate in the apatite. $2 \mathrm{mg}$ of pretreated bone powder was reacted with $100 \% \mathrm{H}_{3} \mathrm{PO}_{4}$ for 90 minutes at $70{ }^{\circ} \mathrm{C}$ using a Thermo Finnigan Gasbench II (Spoetl \& Vennemann 2003). For this reaction an acid fractionation factor of 1.008818, the same as between calcite and $\mathrm{CO}_{2}$, was assumed to be applicable (Bryant et al. 1996). After gas-chromatographic separation and removal of water, the carbon and oxygen isotope ratios of the generated $\mathrm{CO}_{2}$ were measured in continuous flow mode on a Finnigan Delta Plus XL isotope ratio gas mass spectrometer at the University of Tübingen. The measured carbon and oxygen isotopic compositions were normalized to the in-house Carrara marble calcite standard that has been calibrated against the international NBS-19 calcite standard. Precision for the $\delta^{13} \mathrm{C}$ and $\delta^{18} \mathrm{O}$ values of the carbonate in the apatite is better than $\pm 0.1 \%$ and $\pm 0.15 \%$, respectively.

$N$ isotope measurements of total bone powder. Nitrogen is exclusively found in the protein phase of bone (predominantly collagen) (Francillon-Vieillot et al. 1990; Collins et al. 2002). Isotopic analysis of the bone samples was done using $5 \mathrm{mg}$ of untreated bone powder, which were weighed and wrapped into capsulae made from tin foil. The tin capsulae were thermally combusted in a Carlo Erba 2500 Elemental Analyzer at $1050{ }^{\circ} \mathrm{C}$. Exotherm oxidative flash combustion of the tin foil produces temperatures of 1600 to $1800^{\circ} \mathrm{C}$ and reacts with the bone nitrogen bound to the collagen to $\mathrm{NO}_{\mathrm{x}}$. The $\mathrm{NO}_{\mathrm{x}}$ was then reduced in a second step to $\mathrm{N}_{2}$ by flowing over metallic copper heated to $650{ }^{\circ} \mathrm{C}$. The ${ }^{15} \mathrm{~N} /{ }^{14} \mathrm{~N}$ isotope ratios of this $\mathrm{N}_{2}$ was measured in helium continuous flow mode on a Finnigan Delta Plus XL isotope ratio gas mass spectrometer at the University of Tübingen, with a precision of better than $\pm 0.2 \%$. The international urea standard IAEA 305A was measured for calibration.

The isotope compositions are reported in the usual $\delta$-notation in per mil (\%) relative to the known isotope reference standard VPDB $\left(\delta^{13} \mathrm{C}\right)$, VSMOW $\left(\delta^{18} \mathrm{O}\right)$, and AIR $\left(\delta^{15} \mathrm{~N}\right)$ (Coplen 1994):

$\delta^{13} \mathrm{C}, \delta^{15} \mathrm{~N}$ or $\delta^{18} \mathrm{O}(\% \mathrm{o})=\left[\left(\mathrm{R}_{\text {sample }} / \mathrm{R}_{\text {standard }}\right)-1\right] \times 1000$,

where $\mathrm{R}_{\text {sample }}$ and $\mathrm{R}_{\text {standard }}$ are the ${ }^{13} \mathrm{C} /{ }^{12} \mathrm{C},{ }^{15} \mathrm{~N} /{ }^{14} \mathrm{~N}$ and ${ }^{18} \mathrm{O} /{ }^{16} \mathrm{O}$ ratios in the sample and standard, respectively.

\section{Results}

\section{Long bone histology}

The cross-section of the femur has the form of an oval triangle. The inner region is occupied by a round medullary cavity surrounded by cancellous bone (Figs 2A, B), and occupies nearly $53 \%$ of the whole diameter. The centre of the medullary cavity is open and does not show any bone trabeculae or a cancellous structure. This centre fills $43 \%$ of the entire medullary region.

The primary cortex is dominated by parallel-fibred bone in different stages of organization and grades of

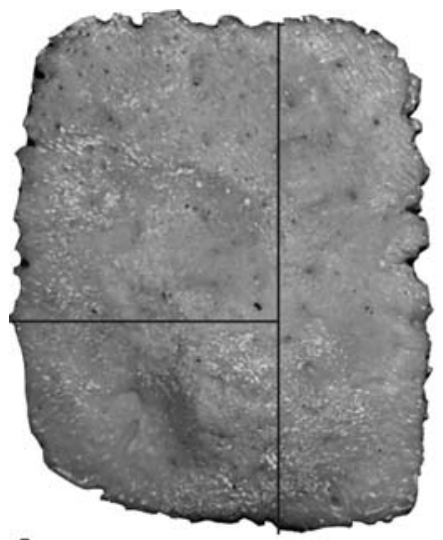

A

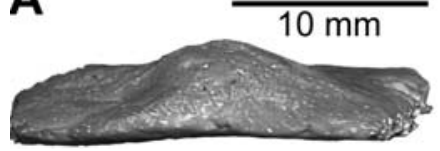

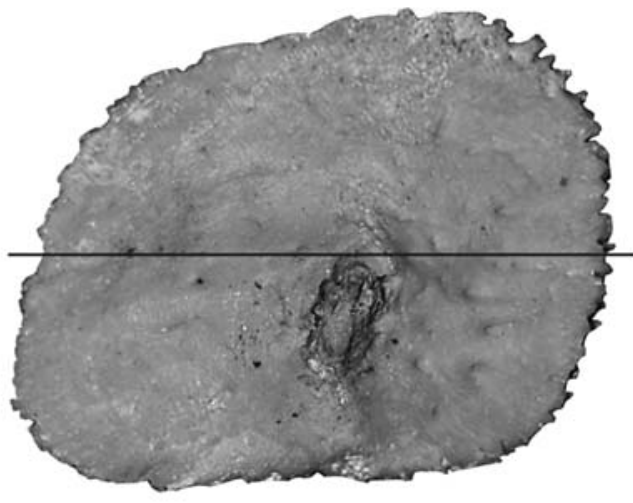

B

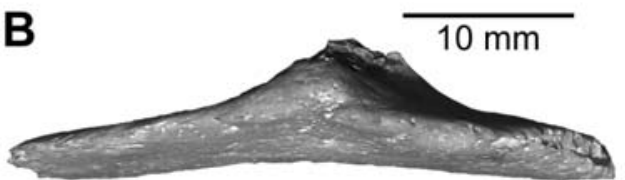

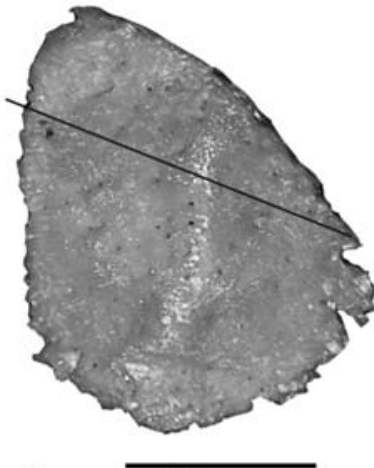

C $10 \mathrm{~mm}$

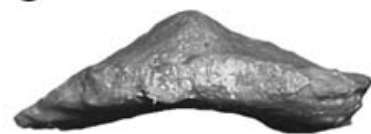

Figure 1. Alligator mississipiensis (Daudin, 1802). Shape of sampled osteoderms of SMNS 10481. A. Rectangular osteoderm (SMNS 10481a) in dorsal and posterolateral view. B. Ovoid osteoderm (SMNS 10481b) in dorsal and anterolateral view. C. Irregular-shaped osteoderm (SMNS 10481c) in dorsal and anterolateral view. Note that the lower images in B and C show osteoderms in an angled view that also indicates the slightly and strongly convex ventral osteoderm surfaces, respectively. Gray lines on osteoderms in dorsal view indicate planes of thin-sectioning. 

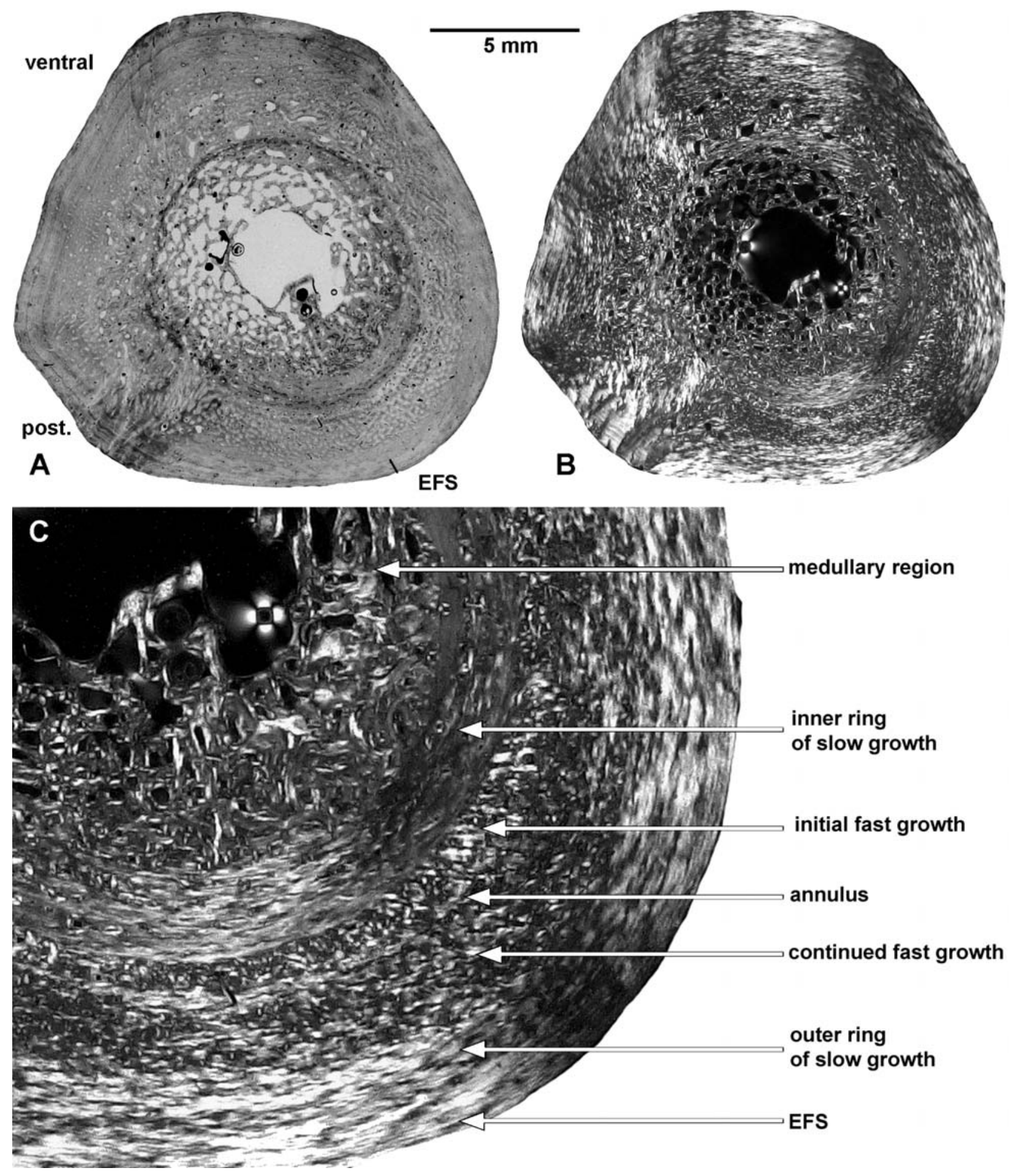

Figure 2. Photograph of the femoral cross-section. A. Under normal transmitted light. Note the orientation of the femur crosssection. B. Under polarized light. Note the changes of highly and poorly organized parallel-fibred bone, which indicate the beginning and end of the three main growth phases. The rectangle marks the region which is magnified and figured in C. C. Detail and interpretation of the dorsal side where the most complete growth record is preserved.

vascularization. The parallel-fibred bone becomes lamellar bone in places. No woven bone could be identified. The simple vascular canals are organized in longitudinal rows. Generally their density is very low. The primary cortex contains no secondary osteons. No endosteal bone surrounds the medullary cavity. Under normal transmitted light, eight growth marks are clearly visible (Fig. 2A). Except for the dorsal side, the inner region contains large resorption cavities but generally only a few large erosion cavities are scattered within the primary cortex.

Cross-polarized light reveals that the medullary region is separated by one LAG (Fig. 2C) from a thick zone of highly organized and poorly vascularized paral- 
lel-fibred bone. This thick zone is also sub-divided by one LAG, and finally ends in another LAG (Fig. 2C).

On the ventral side this zone is distinctly narrower (Figs 2B, C) but clearly corresponds with the outer zone on the dorsal side. Dorsally, this zone is followed by a layer of poorly organized parallel-fibred bone (Fig. 2C), containing longitudinal vascular canals and numerous large osteocyte lacunae. The deposition of poorly organized parallel-fibred bone is interrupted by an annulus (Fig. 2C), which is then followed by one LAG. Both are spaced at regular intervals (Fig. 2C). Ventrally, most of the corresponding area is destroyed by large erosion cavities. Dorsally, a large zone of well organized parallelfibred bone is developed. Here the parallel-fibred bone becomes lamellar bone towards the outer cortex, and finally ends in an external fundamental system (EFS). Ventrally, the transition from the less organized and vascularized parallel-fibred bone into the highly organized and less vascularized parallel-fibred bone is more gradual (Figs 2A, B). Posteriorly, twelve LAGs can be counted within this outer zone of slow growth, whereas on the other sides, only eight or less LAGs can be counted (Fig. 2B). Thus, the growth record is not continuously preserved throughout the entire cross-section. Ventrally, the outer zone of slow growth is larger compared to the dorsal side. On the other hand, most of the inner primary cortex is reabsorbed ventrally, indicating a more active cancellous region in this area.

Altogether, the cross-section shows 17 growth marks (LAGs and annuli) on the dorso-posterior side, the area where the growth record is most complete. However, because of the large medullary cavity it is obvious that some inner growth marks were already resorbed. From the posterior to the ventral side numerous Sharpey's fibres are visible, documenting a massive connection of the adductor femoris muscle with the bone. The fourth trochanter has left no histologic trace.

\section{Gross morphology of sampled osteoderms}

The outlines of the osteoderms SMNS 10481a-c are rectangular to ovoid (Fig. 1). The blunt, longitudinally keeled osteoderm SMNS 10481a is a median paravertebral osteoderm, SMNS 10481 b is considered to be part of the left lateral paravertebral row, whereas SMNS 10481c might have been situated in one of the accessory rows of osteoderms in the trunk of the animal, but, the exact position cannot be assessed with certainty. The dorsal surfaces of all three osteoderms lack a clear pattern of pits but small foramina extend into the bone interior. SMNS 10481b, the apex of the keel, which is situated in the presumed posterior part of the osteoderm is pathologic (Fig. 1B); an osteomalacia possibly related to the hypothermic and rachitic condition (pers. comm. Ch. Wermuth 2008) the animal developed before it recovered in the care of Dr. $\mathrm{H}$. Wermuth, SMNS. The ventral surface of SMNS 10481c is more concave than to that of the other two specimens (Fig. 1). Sutures are present on all margins in osteoderm SMNS 10481a only (Fig. 1A).

\section{Osteoderm histology}

All three osteoderms (Fig. 3) show similar microstructures, so they will be described in one section. Indivi-
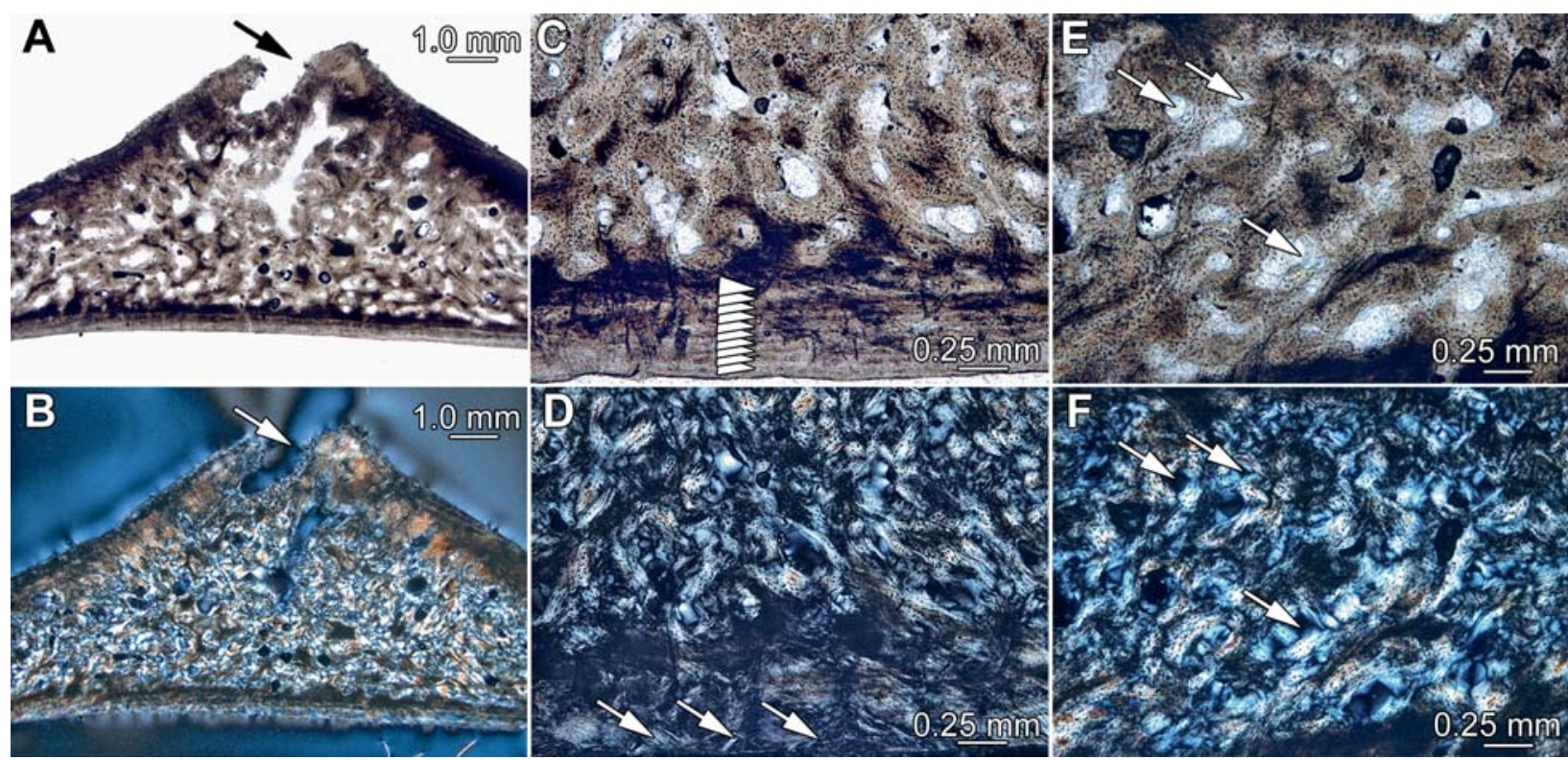

Figure 3. Bone histology of sampled osteoderms of SMNS 10481. Images A, C, and E are in normal transmitted light, images B, D, and F in polarized light. A, B. Overview of SMNS 10481b, which shows the outer compacta surrounding remodeled cancellous bone. The pathologic groove on the keel in this specimen is indicated by arrows. C, D. Close-up view of the internal cortex (basal cortex of osteoderm) and lower part of the interior remodeled area of SMNS 10481a. In C, the stack of white arrows indicates ten growth marks within the compact bone. In D, the three white arrows point to some of the angled Sharpey's fibres, which insert into the compact parallel-fibred bone tissue. E, F. Close-up view of the interior remodeled cancellous bone of SMNS 10481b. The white arrows indicate vascular canals in a densely remodeled compact spongiosa. 
dual variation among the specimens will be mentioned if applicable. None of the specimens show any indication of a remodeled pattern of pits in thin-section. The osteoderms all have a diploe structure with compact cortical bone surrounding a more cancellous bone core. The compact cortical bone comprises about 30-50\% of the thin-sections. Osteoderm SMNS 10481a has a maximum thickness (measured at keel) of $4 \mathrm{~mm}$, with the dorsal and ventral cortices ranging between $0.7-$ $0.8 \mathrm{~mm}$ and $0.5-0.55 \mathrm{~mm}$ in thickness respectively, whereas in the anterior part of the osteoderm, maximum thickness is only $2.5-2.6 \mathrm{~mm}$, with the cortical thickness still within the range of those measured at the keel.

The cortical bone layer consists of parallel-fibred bone and lamellar-zonal bone is developed locally. The cortices are poorly vascularized with scattered, primary (simple) vascular canals. In osteoderm SMNS 10481a, a major nutritional foramen/canal extends dorsoventrally through the osteoderm. In osteoderm SMNS 10481b the dorsal bone surface at the apical part of the keel is deeply eroded and scalloped (Figs 3A, B).

The Sharpey's fibres insert at sharp angles into the dorsal and ventral cortical bone, whereas they insert more perpendicular to the bone surface at the sutured margins of the osteoderms. Sharpey's fibres are finer and more evenly distributed in the dorsal and marginal cortices, whereas they are coarsely bundled and more widely spaced in the ventral cortical bone layers (Figs 3C, D). In the ventral cortex of osteoderm SMNS 10481c, the Sharpey's fibres are less prominent and less coarsely bundled.

The interior bone of the specimens is cancellous (Figs 3A, B), with the interior part of the osteoderm being strongly affected by successive resorption and reconstruction of bone tissue (Figs 3E, F). Large vascular cavities and long bony trabeculae are not observable. Only a few scattered remnants of primary bone tissue of interwoven structural fibre bundles are preserved. The interior skeletal tissue comprises scattered primary osteons and primary canals, often secondarily enlarged, in the remnants of primary tissue, but the main bulk of interior vascularization consists of the canals of successive generations of irregularly arranged secondary osteons and erosion cavities.

Growth marks, i.e., annuli and zones, within the cortices are largely obscured by Sharpey's fibres. The best growth record was preserved within the ventral and marginal cortical bone of the posterior part of the os-

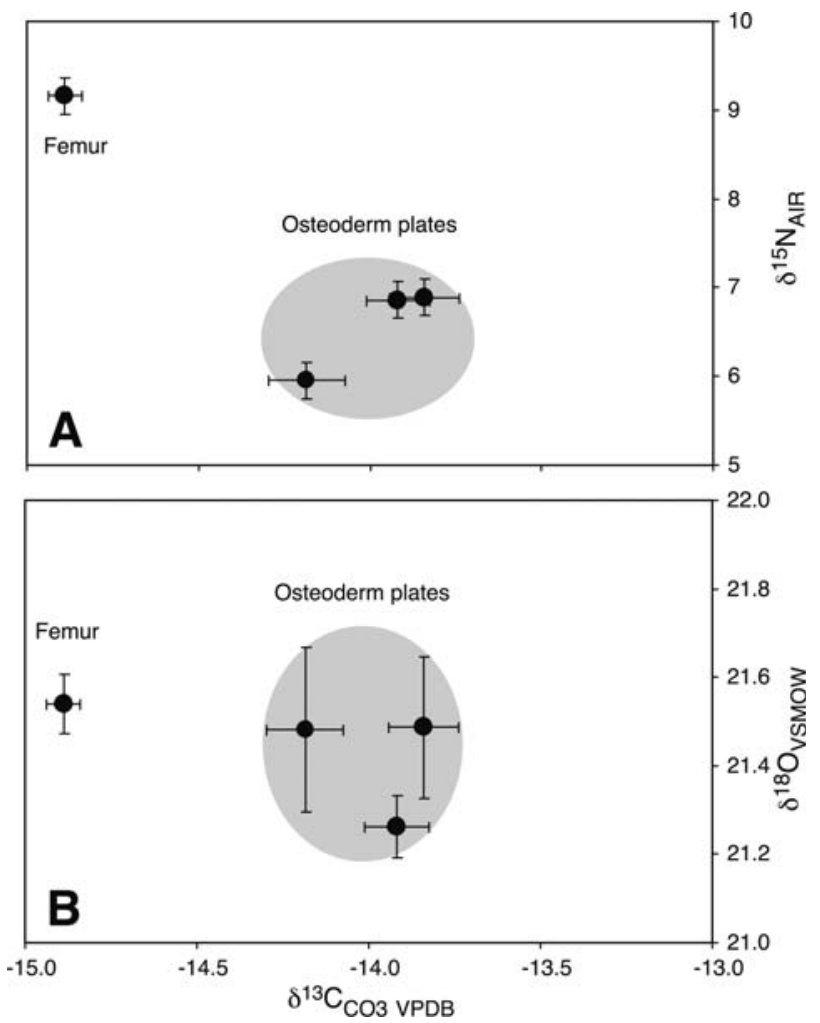

Figure 4. Isotope compositions of the osteoderm plates and the femur of the alligator. A. Carbon $\left(\delta^{13} \mathrm{C}_{\mathrm{CO} 3}\right)$ and nitrogen $\left(\delta^{15} \mathrm{~N}\right)$. B. Carbon $\left(\delta^{13} \mathrm{C}_{\mathrm{CO} 3}\right)$ and oxygen $\left(\delta^{18} \mathrm{O}_{\mathrm{CO} 3}\right)$.

teoderm SMNS 10481a (Fig. 3C). Here, a total of ten growth marks was counted, i.e., LAGs. In the cortical bone of the other osteoderms only about five to seven growth marks are visible at best. No growth marks are visible in the interior cancellous parts of the osteoderms (Figs 3E, F).

\section{Isotope results}

The $\delta^{15} \mathrm{~N}$ values of the three osteoderms $\left(\delta^{15} \mathrm{~N}=5.9\right.$ to $6.9 \%$ ) are about 2 to $3 \%$ lower than that of the femur $\left(\delta^{15} \mathrm{~N}=9.2 \%\right.$ ) (Fig. 4A, Tab. 1). Nitrogen content of the osteoderm plates (4.2 to $4.4 \mathrm{wt} \%$ ) and the femur (3.8 wt \%) are slightly different but both fall in the range typical of fresh bone $(\sim 4 \pm 0.5 \mathrm{wt} \%$; Tütken 2003).

The carbonate of the bone apatite of the osteoderm plates has slightly lower $\delta^{13} \mathrm{C}$ values of -13.8 to $14.2 \%$ o than the femur $-14.9 \%$ (Fig. $3 b$ ). $\delta^{18} \mathrm{O}_{\text {VSMOW }}$ values of all bone samples are very similar and range

Table 1. C, N, and O isotope compositions of the alligator bones.

\begin{tabular}{|c|c|c|c|c|c|c|c|c|c|}
\hline Sample & Specimen-no & bone & $\delta^{13} C_{V P D B}$ & $\sigma$ & $\mathrm{CO}_{3} \mathrm{wt} \%$ & $\delta^{18} O_{\text {vsmow }}$ & $\sigma$ & $\delta^{15} N_{A I R}$ & $\mathrm{~N}$ wt $\%$ \\
\hline KST1 & SMNS 10481 & osteoderm & -14.2 & 0.1 & 4.1 & 21.5 & 0.2 & 5.9 & 4.2 \\
\hline KST2 & SMNS 10481 & osteoderm & -13.9 & 0.1 & 4.4 & 21.3 & 0.1 & 6.9 & 4.4 \\
\hline KST3 & SMNS 10481 & osteoderm & -13.8 & 0.1 & 3.8 & 21.5 & 0.2 & 6.9 & 4.3 \\
\hline KST4 & SMNS 10481 & femur & -14.9 & 0.0 & 5.8 & 21.5 & 0.1 & 9.2 & 3.8 \\
\hline
\end{tabular}


from 21.3 to $21.5 \%$, and the osteoderm plates and the femur have within analytical error identical $\delta^{18} \mathrm{O}$ values (Fig. 4B, Tab. 1).

\section{Discussion}

\section{Long bone}

The primary bone tissue and resorption pattern characteristic for crocodilians (Peabody 1961; Ricqlès 1976a, 1976b; Padian et al. 2004; Lee 2004) can be found also in femur SMNS 10481. The degree for porosity in the medullary cavity as well as the porosity beyond the medullary cavity is in accordance with an egg-laying female (Wink \& Elsey 1986: figs 1, 2).

In our interpretation of the growth record, three main phases of growth can be distinguished. The inner zone of less vascularized and highly organized parallel-fibred bone tissue reflects a low growth rate compared to what is expected form normal growth in juvenile alligators over a long time period ( $28 \%$ of the preserved growth record/bone tissue). Such a slow growth would rather be expected in a late ontogenetic stage (see Klein \& Sander 2008 for dinosaur long bones). We conclude that this first growth phase represents the time, or at least the latter part of the time, the alligator lived in the leisure park in Switzerland. This early low growth rate probably reflects the poor environmental conditions (climate and food) the alligator was kept in. This is supported by the fact that the circumference of this inner zone fits approximately with that of an animal that is $100 \mathrm{~cm}$ in length (Farlow et al. 2005). Assuming the LAGs were deposited annually, they suggest that the alligator lived there for at least 3 years.

After an initial phase of lasted slow growth, the growth rate of the alligator began to increase, in our interpretation, at least for one year. Then a second phase followed, where the growth rate was still high. Due to the deposited growth marks, this phase lasts for at least two more years. The bone that was formed during both fast growth phases makes up $40 \%$ of the preserved growth record. We interpret this very fast growth rate as a result of the optimized living conditions it received after it was transferred to Ludwigsburg, where the alligator could continue its growth to a mature adult. The last phase of growth was again a period of slow growth, which finally ceased. The final decrease in growth was initiated because of the endogen constrictions of the individual (i.e., onset of sexual maturity). This permanent slow down in growth lasted for around 13 years and built $32 \%$ of the preserved primary cortex.

The most complete growth record is on the dorsoposterior side preserved. Here, 17 growth marks (annuli, LAGs) are deposited, which correspond to 18 cycles or years. Although the alligator experienced a period of fast growth under optimal conditions of climate and food, no woven bone or fibro-lamellar bone type was identified.
Our study provides partial support for the use of bone histology and skeletochronology to learn about the life histories of extinct animals. However, our results must be used with caution because the data is based on only a single captive (= atypical conditions) individual. Additionally, neither the exact ontogenetic age nor the diet of early life history are known.

Our study demonstrates that the number of growth marks beyond the medullary cavity does not reflect the time (in years) the individual was supposed to have lived since it left the leisure park in Switzerland. The growth record in the femur of SMNS 10481 documents, in our interpretation, a minimum of 18 years of the life history of this individual. Therefore the preserved growth record includes the time or at least the end of that time period when the alligator lived in Switzerland. To give a more exact age of that individual, 23-25 growth marks should have been preserved, since it lived 20 to 21 years after leaving the leisure park in 1969 . However, it is not unusual that growing crocodilians do not deposit annual growth marks (Padian et al. 2004). Thus, the second fast-growing period may comprise several years and not only two, as documented by the deposited growth marks.

Additionally, it is not known if the alligator was a hatchling or already a few years old when it came to Switzerland. Some growth marks were already reabsorbed because of the normal expansion of the medullary cavity. When the specimen moved to Ludwigsburg, at least one to three of the initial growth marks may have already been destroyed, according to the size of the alligator (Tucker 1997; Ross 2002).

A similar high number of thick Sharpey's fibres at the posteroventral side of the femur as in specimen SMNS 10481 has not been noted before in crocodiles (e.g., Ricqlès et al. 2003; Padian et al. 2004; Chinsamy \& Hillenius 2004). A possible hypothesis is that the alligator under study had retained from its rachitis a false anatomical position of extremities. This could have led to an unusually pronounced adductor femoris muscle with a stronger histological connection to the bone than usual. However, this is only hypothetical because even less research has focused on microanatomical features in studies on crocodilian long bones.

\section{Osteoderms}

As expressed by Hutton (1986), the cortical bone structure of osteoderms of (Nile) crocodiles is related to an individual's sex and reproductive status. The low number of visible growth marks (a maximum of ten annuli and zones), as well as the strongly remodeled interior cancellous part of our alligator specimens are consistent with histological results for osteoderms of female crocodile specimens. Our findings corroborate Hutton's (1986) data on captive Nile crocodiles, Crocodylus niloticus Laurenti, 1768, and Tucker's (1997) data on osteoderm-based age estimates of wild Australian freshwater crocodiles, Crocodylus johnstoni Krefft, 1873. In 
both Crocodylus species, growth counts based on visible annuli in breeding females generally led to an underestimation of age. A mean of eight visible annuli was recorded in the ten largest breeding females of Crocodylus johnstoni, although seven of these females had documented breeding histories from 12-20 years (Tucker 1997: pp. 346-347). In both crocodile species, osteoderms of females that had not yet reached sexual maturity showed unremodeled growth marks (Hutton 1986; Tucker 1997).

The osteoderms of our alligator specimen would presumably fall into the readability code S3, the group that was not taken for liable age estimation by Tucker (1997). The high resorption processes in the cancellous regions of the sampled osteoderms could have different causes however: First, the observable remodeling processes in osteoderms could be linked to increased calcium requirements in egg-laying females in both crocodile and alligator species. In this regard, osteoderms of crocodilian species differ from the shells of turtles that are not used preferentially as calcium reservoirs (in contrast to turtle long bones) during gravidity and oviposition (Suzuki 1963). Second, the resorption of bone tissue might be caused by a pathologic calcium deficiency often encountered in captive reptiles (e.g., Frye 1991).

\section{Bone isotope compositions}

Different bones have different remodeling rates that can range from a few years to decades, depending on bone type. The bone remodeling rate determines how fast a bone equilibrates with the isotopic composition of the diet and drinking water. Thus the isotopic composition of the bone apatite and collagen should reflect the mean composition of the food and drinking water during the last years of life. Remodeling rates of osteoderm plates seem to be significantly higher than for the femur where most resorption occurs (Hutton 1986; Tucker 1997). Therefore osteoderm plates should reflect in their isotopic composition the last years of life whereas the femur may still preserve isotopic compositions of older ontogenetic periods of life. This might be the cause for differences in carbon and nitrogen isotopic composition between osteoderm plates and the femur (Figs 4A, B).

The nitrogen isotope composition of an animal is related to its food source and the trophic level within an ecosystem (DeNiro \& Epstein 1981; Minangawa \& Wada 1984). Protein in consumers have a higher ${ }^{15} \mathrm{~N} /{ }^{14} \mathrm{~N}$ ratio than dietary protein and animals in neutral nitrogen balance typically show fractionations ranging from $2 \%$ to $5 \%$ (DeNiro \& Epstein 1981) between dietary nitrogen and tissue nitrogen. Because a consumer's nitrogen is heavier than its diet, nitrogen in the tissues of animals higher in the food chain tends to be heavier (i.e., to have more positive $\delta^{15} \mathrm{~N}$ values) than that of animals lower in the food chain (Minagawa \& Wada 1984). This can be used to determine trophic levels in food webs. Because starving animals literally "live on their own meat", the mechanisms by which their tissues become enriched in ${ }^{15} \mathrm{~N}$ are the same as those causing trophic-level nitrogen fractionation. This is because excreted nitrogen contained in ammonia, urea, and uric acid is isotopically lighter than body and dietary protein (Steele \& Daniel 1978). The excreted "lighter" nitrogen is not replaced by dietary protein; therefore, the animal becomes progressively more ${ }^{15} \mathrm{~N}$ enriched over the course of starvation. The tissues of starving animals show a progressive increase in the ${ }^{15} \mathrm{~N} /{ }^{14} \mathrm{~N}$ ratio as lean body mass decreases (Hobson et al. 1993). Due to intense remodeling the isotopic composition of the osteoderms used in this study reflect the diet of the more recent Stuttgart period. In contrast the femur might still partly contain remnant dietary $\delta^{15} \mathrm{~N}$ values of the starvation period in the Swiss leisure park or at least contains a dietary record of a longer time period than the osteoderms. Therefore it is likely that starvation and not feeding on a more ${ }^{15} \mathrm{~N}$-enriched diet such as a higher portion of animal proteins, is the cause for the $\sim 3 \%$ higher $\delta^{15} \mathrm{~N}$ values (which represents about one trophic level difference (Minagawa \& Wada 1984)) of the femur compared to the osteoderm plates of the alligator.

The mean $\delta^{13} \mathrm{C}$ value $-14.2 \pm 0.5 \%$ of the osteoderm plates and femur is typical for a vertebrate feeding in a $\mathrm{C}_{3}$ plant based foodweb (Cerling et al. 1997). Thus the animals (teleosts and chicken) that were predominantly fed to the alligator were raised on a $\mathrm{C}_{3}$ plant diet. The oxygen isotope composition of all bones is very similar and indicates that the alligator drank water with similar $\delta^{18} \mathrm{O}$ values. From the mean $\delta^{18} \mathrm{O}_{\mathrm{CO} 3}=21.4 \pm 0.1 \%$ o VSMOW of the bone specimens the phosphate oxygen isotope compositions $\left(\delta^{18} \mathrm{O}_{\mathrm{PO} 4}\right)$ can be calculated using the $\delta^{18} \mathrm{O}_{\mathrm{CO} 3}-\delta^{18} \mathrm{O}_{\mathrm{PO} 4}$-equlibrium equation for mammal bone of Iacumin et al. (1996). Using this $\delta^{18} \mathrm{O}_{\mathrm{PO} 4}$ value of $12.5 \%$, a drinking water $\delta^{18} \mathrm{O}_{\mathrm{H} 2 \mathrm{O}}$ value of $-8.9 \pm 0.1 \%$ VSMOW can be calculated using the empirical $\delta^{18} \mathrm{O}_{\mathrm{H} 2 \mathrm{O}}-\delta^{18} \mathrm{O}_{\mathrm{PO} 4}$ fractionation equation for modern crocodiles of Amiot et al. (2007). The value of $-8.9 \%$ is typical for the $\delta^{18} \mathrm{O}_{\mathrm{H} 2 \mathrm{O}}$ values of precipitation/ meteoric water in SW Germany (Rozanski 1995) in the vicinity of Stuttgart where the alligator lived during the last approximately 20 years of his life. However, similar $\delta^{18} \mathrm{O}_{\mathrm{H} 2 \mathrm{O}}$ values do also occur in the precipitation of Swiss lowland localities (Schürch et al. 2003). This might explain that no difference in $\delta^{18} \mathrm{O}_{\mathrm{CO} 3}$ values could be observed between the osteoderms and the femur bone of the alligator. A more detailed intra bone isotopic analysis of the different histological growth zones can help to further refine the bone growth record by inferring the change of residence and thus likely isotopic composition of the food and water resources used.

\section{Conclusions}

The bone histology as seen in the femoral cross-section depicts the unstable life history of this individual. However, besides resorption and remodeling processes, 
which eliminated early growth marks, the preserved growth record may also be incomplete. For the study of fossils, such age estimations may be adequate, although data gathered from growth series are more reliable. For ecological/population studies such age estimations are obviously not sufficient. Furthermore, the current long bone histological sample supports previous observations that crocodilians are not restricted to the lamellar-zonal bone type but show a wide range of bone tissue types which can span from the entirely lamellar-zonal bone type (Ricqlès et al. 2003; Padian et al. 2004; Lee 2004; Lee \& Werning 2008) to the fibro-lamellar complex (Reid 1984, 1997; Chinsamy \& Hillenius 2004; Turmarkin-Deratzian 2007). However, although specimen SMNS 10481 experienced a phase of atypical fast growth (at least for an alligator), no fibro-lamellar bone was deposited. Growth with fibro-lamellar bone could possibly be constrained by this special individual due to its advanced age or its poor health when fast growth first started. This would contradict the observations of Turmarkin-Deratzian (2007: p. 344), who had stated that fibro-lamellar bone is not necessarily "restricted (to captive,) juvenile, or even optimally healthy individuals".

The current study further affirms that osteoderms are not well suited for the skeletochronology in egg-laying females of Alligator mississippiensis. This also implies a more careful use of osteoderms in skeletochronology of fossil specimens

The measured $\mathrm{C}, \mathrm{O}$, and $\mathrm{N}$ isotope compositions of the alligator bones agree with the food and water ingested during most of its life. Similar oxygen isotope compositions of osteoderm and femora indicate ingestion of water with a $\delta^{18} \mathrm{O}$ value of around $-9 \%$. A slight and a major difference in carbon and nitrogen isotopic composition, respectively, were observed between the femur and the osteoderms. Though the exact cause for these differences is not clear, the higher $\delta^{15} \mathrm{~N}$ values in the femur are possibly related to starvation of the alligator during early ontogeny. These isotope differences have been preserved due to different bone resorption and remodeling rates of alligator long bones and osteoderms which must be taken into account when conducting isotope analyses on crocodilian bones. Intra bone isotopic analysis of non-remodeled long bones can potentially allow isotopic life history of individual crocodilians to be inferred. This may help, in conjunction with histological observations, to further refine the growth record of individuals.

\section{Acknowledgements}

We are very thankful to D. Mörike (SMNS) who provided us with the material, the permission for sampling, and further information about the alligator. We also would like to thank Ch. Wermuth, the daughter of Dr. H. Wermuth, who gave us valuable information about the life history of this alligator. We gratefully acknowledge O. Dülfer (Steinmann Institut, Bonn) for the preparation of long bone and osteoderm thin-sections. NK thanks G. Oleschinski (Steinmann Institut, Bonn) for the photographs of the femur cross-section, and the DFG for funding (KL2127/1-1). TT acknowledges funding by the Emmy Noether Program of the DFG grant TU 148/2-1. We thank S. Viehmann (Steinmann Institut, Bonn) and B. Steinhilber (Institut für Geowissenschaften, Tübingen) for bone sampling/pretreatment and measuring isotope compositions, respectively. We like to thank M. Laurin, V. de Buffrénil, J. Botha-Brink, and an anonymous reviewer for their remarks that greatly improved earlier versions of the manuscript. S. Walton (Berlin) is acknowledged for improving English grammar and style. This is contribution number 48 of the DFG Research Unit 533 "Biology of the Sauropod Dinosaurs".

\section{References}

Amiot, R., Lécuyer, C., Buffetaut, E., Escarguel, G., Fluteau, F. \& Martineau, F. 2006. Oxygen isotopes from biogenic apatites suggest widespread endothermy in Cretaceous dinosaurs. - Earth and Planetary Science Letters 246: 41-54.

Amiot, R., Lécuyer, C., Escarguel, G., Billon-Bruyat, J.-P., Buffetaut, E., Langlois, C., Martin, S., Martineau, F. \& Mazin, J.-M. 2007. Oxygen isotope fractionation between crocodilian phosphate and water. - Palaeogeography, Palaeoecology, Palaeoclimatology 243: 412-420.

Björndal, K., Bolten, A. B., Bennett, R. A., Jacobson, E. R., Wronski, T. J., Valeski, J. J. \& Elizar, P. J. 1998. Age and growth in sea turtles: limitations of skeletochronology for demographic studies. Copeia 1: 23-30.

Bryant, J. D., Koch, P. L., Froelich, P. N., Showers, W. J. \& Genna, B. J. 1996. Oxygen isotope partitioning between phosphate and carbonate in mammalian apatite. - Geochimica et Cosmochimica Acta 60: 5145-5148.

Buffrénil, V. de 1980a. Preliminary data on the structure of growth marks among living and fossil crocodilians. - Bulletin de la Société Zoologique de France 105 (2): 355-361.

Buffrénil, V. de 1980b. Mise en evidence de l'incidence des conditions de milieu sur la croissance de Crocodylus siamensis Schneider, 1801 et valeur des marques de croissance squelettiques pour l'évaluation de 1' âge individuel. - Archives de Zoologie experimentale et générale 121 (1): 63-76.

Buffrénil, V. de \& Buffetaut, E. 1981. Skeletal growth lines in an Eocene crocodilian skull from Wyoming as an indicator of ontogenetic age and paleoclimatic conditions. - Journal of Vertebrate Paleontology 1: 57-66.

Buffrénil V. de \& Castanet, J. 2000. Age estimation by skeletochronology in the Nile monitor (Varanus niloticus), a highly exploited species. - Journal of Herpetology 34: 414-424.

Bybee, P. J., Lee, A. H. \& Lamm, E.-T. 2006. Sizing the Jurassic Theropod Dinosaur Allosaurus: Assessing Growth Strategy and Evolution of Ontogenetic Scaling of Limbs. - Journal of Morphology 267 (3): 347-359.

Castanet, J. 1994. Age estimation and longevity in reptiles. - Gerontology 40: 174-192.

Castanet, J. \& Smirina, E. 1990. Introduction to the skeletochronological method in amphibians and reptiles. - Annales des Sciences Naturelles, Zoologie 11: 191-196.

Castanet, J., Newman, D. G. \& Saint Girons, H. 1988. Skeletochronological data on the growth, age, and population structure of the tuatara, Sphenodon punctatus, on Stephens and Lady Alice islands, New Zealand. - Herpetologica 44: 25-37.

Castanet, J., Francillon-Vieillot, H., Meunier, F. J. \& Ricqlès, A. de 1993. Bone and individual aging. In Hall, B. K. (ed.). Bone Volume 7: Bone Growth - B. CRC Press, Boca Raton: pp. 245-283.

Cerling, T. E., Harris, J. M., MacFadden, B. J., Leakey, M. G., Quade, J., Eisenmann, V. \& Ehleringer, J. R. 1997. Global vegetation change through the Miocene-Pliocene boundary. - Nature 389: $153-158$. 
Chinsamy, A. 1990. Physiological implications of the bone histology of Syntarsus rhodesiensis (Saurischia: Theropoda). - Palaeontologia africana 27: 77-82.

Chinsamy, A. 1993. Bone histology and growth trajectory of the prosauropod dinosaur Massospondylus carinatus (Owen). - Modern Geology 18: 319-329.

Chinsamy, A. \& Hillenius, W. J. 2004. Physiology of nonavian dinosaurs. In Weishampel, D. B., Dodson, P. \& Osmolska, H. (eds). The Dinosauria. Second edition. University of California Press, Berkeley, CA: pp. 643-659.

Chinsamy-Turan, A. 2005. The microstructure of dinosaur Bone. John Hopkins University Press, Baltimore.

Collins, M. J., Nielsen-Marsh, C. M., Hiller, J., Smith, C. I., Roberts, J. P., Prigodich, R. V., Wess, T. J., Csapò, J., Millard, A. R. \& Turner-Walker, G. 2002. The survival of organic matter in bone: a review. - Archaeometry 44: 383-394.

Coplen T. B. 1994. Reporting of stable hydrogen, carbon, and oxygen isotopic abundances. - Pure Applied Chemistry 66: 273-276.

Daudin, F. M. 1802. Histoire Naturelle Générale et Particulière des Reptiles. Volume 2. Dufart, Paris.

DeNiro, M. J. \& Epstein, S. 1981. Influence of diet on the distribution of nitrogen isotopes in animals. - Geochimica et Cosmochimica Acta 45: 341-351.

Enlow, D. H. \& Brown, S. O. 1957. A comparative histological study of fossil and Recent bone tissues. Part II. - The Texas Journal of Science 9: 186-214.

Erickson, G. \& Tumanova, T. A. 2000. Growth curve of Psittacosaurus mongoliensis Osborn (Ceratopsia: Psittacosauridae) inferred from long bone histology. - Zoological Journal of the Linnean Society 130: 551-566.

Erickson, G., Makovicky, P. J., Currie, P., Norell, M., Yerby, S. A. \& Brochu, C. A. 2004. Gigantism and comparative life-history parameters of tyrannosaurid dinosaurs. - Nature 430: 772-775.

Erickson, G. M. 2005. Assessing dinosaur growth patterns: a microscopic revolution. - Trends in Ecology and Evolution 20 (12): 677-684.

Farlow, J. O., Hurlburt, G. R., Elsey, R. M., Britton, A. R. C. \& Langston J. W. 2005. Femoral dimensions and body size of Alligator mississippiensis: Estimating the size of extinct mesoeurcrocodylians. - Journal of Vertebrate Paleontology 25 (2): 354-369.

Francillon-Vieillot, H., Castanet, J., Geraude, J., Meunier, F. J., Sire, J. Y., Zylberberg, L. \& Ricqlès, A. de. 1990. Microstructure and mineralization of vertebrate skeletal tissues. In Carter, J. E. (ed.). Skeletal biomineralization: patterns, processes and evolutionary trends. Van Nostrand Reinhold, New York, NY: pp. 471-530.

Fricke, H. C. \& Rogers, R. R. 2000. Multiple taxon-multiple locality approach to providing oxygen isotope evidence for warm-blooded theropod dinosaurs. - Geology 28: 799-802.

Frye, F. L. 1991. Reptile Care, an Atlas of Diseases and Treatments (Vol. 1 \& 2). T. F. H. Publications, Neptune City.

Hayashi, S. \& Carpenter, K. 2007. Different growth patterns between the body skeleton and osteoderms of Stegosaurus (Ornithischia: Threophora). - Journal of Vertebrate Paleontology 27 (Suppl.): 88A.

Hill, R. V. \& Lucas, S. G. 2006. New data on the anatomy and relationships of the Paleocene crocodylian Akanthosuchus langstoni. Acta Palaeontologica Polonica 51: 455-464.

Hobson, K. A., Alisauskas, R. T. \& Clark, R. G. 1993. Stable nitrogen isotope enrichment in avian tissues due to fasting and nutritional stress: Implications for isotopic analysis of diet. - Condor 95: 388-394

Horner, J. R., Ricqlès, A. de \& Padian, K. 1999. Variation in dinosaur skeletochronology indicators: implications for age assessment and physiology. - Paleobiology 25: 295-304.

Horner, J. R., Ricqlès, A. de \& Padian, K. 2000. Long bone histology of the hadrosaurid dinosaur Maiasaura peeblesorum: growth dynamics and physiology based on an ontogenetic series of skeletal elements. - Journal of Vertebrate Paleontology 20: 115-129.
Hua, S. \& Buffrénil, V. de. 1996. Bone histology as a clue in the interpretation of functional adaptations in the Thalattosuchia (Reptilia, Crocodylia). - Journal of Vertebrate Paleontology 16: $703-717$.

Hutton, J. M. 1986. Age determination of living Nile crocodiles from the cortical stratification of bone. - Copeia 2: 332-341.

Iacumin, P., Bocherens, H., Mariotti, A. \& Longinelli, A. 1996. Oxygen isotope analyses of co-existing carbonate and phosphate in biogenic apatite: a way to monitor diagenetic alteration of bone phosphate. - Earth and Planetary Science Letters 142: 1-6.

Jacobsen, T. \& Kushlan, J. A. 1989. Growth dynamics in the American alligator (Alligator mississipiensis). - Journal of Zoology 219: 309-328.

Klein, N. \& Sander, P. M. 2007. Bone histology and growth of the prosauropod dinosaur Plateosaurus engelhardti von Meyer, 1837 from the Norian bonebeds of Trossingen (Germany) and Frick (Switzerland). - Special Papers in Palaeontology 77: 169-206.

Klein, N. \& Sander, P. M. 2008. Ontogenetic stages in the long bone histology of sauropod dinosaurs. - Paleobiology 34 (2): 247-263.

Koch, P. L. 2007. Isotopic study of the biology of modern and fossil vertebrates. In Michener, R. \& Lajtha, K. (eds). Stable Isotopes in Ecology and Envrionmental Science, Second edition. Blackwell, Oxford: pp. 99-154.

Kohn, M. J. \& Cerling, T. E. 2002. Stable isotope compositions of biological apatite. In Kohn, M. J., Rakovan, J. \& Hughes, J. M. (eds). Phosphates: Geochemical, Geobiological, and Materials Importance. - Reviews in Mineralogy and Geochemistry 48: 455488

Krefft, G. 1873. Remarks on Australian crocodiles, and a description of a new species. - Proceedings of the Zoological Society of London 1873: 334-335.

Laurenti, J. N. 1768. Specimen Medicum, Exhibens Synopsin Reptilium Emendatum cum Experimentatis Circa Venena et Antiodota Reptilium Austriacorum. J. T. de Trattern, Vienna.

Lee, A. 2004. Histological organization and its relationship to function in the femur of Alligator mississipiensis. - Journal of Anatomy 204: 197-207.

Lee, A. \& Werning, S. 2008. Sexual maturity in growing dinosaurs does not fit reptilian growth models. - Proceedings of the National Academy of Sciences 105 (2): 582-587.

Minagawa, M. \& Wada, E. 1984. Stepwise enrichment of ${ }^{15} \mathrm{~N}$ along food chains; further evidence and the relation between delta ${ }^{15} \mathrm{~N}$ and animal age. - Geochimica et Cosmochimica Acta 48: 11351140 .

Neill, W. T. 1971. The Last of the Ruling reptiles - Alligators, Crocodiles and their Kin. Columbia University Press, New York.

Padian, K. \& Horner, J. R. 2004. Dinosaur Physiology. In Weishampel, D. B., Dodson, P. \& Osmolska, H. (eds). The Dinosauria. Second edition. University of California Press, Berkeley, CA: pp. 660-671.

Padian, K., Horner, J. R., \& Ricqlès, A. de. 2004. Growth in small dinosaurs and pterosaurs: The evolution of archosaurian growth strategies. - Journal of Vertebrate Paleontology 24 (3): 555-571.

Peabody, F. E. 1961. Annual growth zones in living and fossil vertebrates. - Journal of Morphology 108: 11-62.

Reid, R. E. H. 1984. Primary bone and dinosaurian physiology. Geological Magazine 121: 589-598.

Reid, R. E. H. 1997. How dinosaurs grew. In Farlow, J. O. \& BrettSurmann, M. K. (eds). The Complete Dinosaur. Indiana University Press, Bloomington: pp. 403-413.

Ricqlès, A. de 1968. Recherches paléohistologiques sur les os longs des tétrapodes. I. Origine du tissu osseux plexiforme des dinosaurians sauropodes. - Annales de Paléontologie 54: 133-145.

Ricqlès, A. de 1976a. Recherches paléohistologiques sur les os longs des tétrapodes. VII. Sur le classification, la significationfonctionelle et l'histoire des tissus osseux des tétrapodes. - Annales de Paléontologie 62: 71-126. 
Ricqlès, A. de 1976b. On bone histology of fossil and living reptiles, with comments on its functional and evolutionary significance. In Bellairs, A. d'A. \& Cox, B. C. (eds). Morphology and Biology of Reptiles. Academic Press, London: pp. 123-150.

Ricqlès, A. de, Padian, K. \& Horner, J. R. 2003. On the bone histology of some Triassic pseudosuchian archosaurs and related taxa. - Annales de Paléontologie 89: 67-101.

Ricqlès, A. de, Padian, K., Knoll, F. \& Horner, J. R. 2008. On the origin of high growth rates in archosaurs and their ancient relatives: complementary histological studies on Triassic archosauriforms and the problem of a "phylogenetic signal" in bone histology. - Annales de Paléontologie 94 (2): 57-76.

Ross, C. A. 2002. Krokodile und Alligatoren. Entwicklung, Biologie und Verbreitung. Bassermann Verlag, München.

Rozanski, K. 1995. Climatic control of stable isotopes in precipitation as a basis for palaeoclimatic reconstruction. In Frenzel, B., Stauffer, B. \& Weiß, M. (eds). Problems of stable isotopes in treerings, lake sediments and peat-bogs as climatic evidence for the Holocene. Fischer, Stuttgart, Jena, New York: pp. 171-186.

Sanchez, S., Klembara, J., Castanet, J. \& Steyer, J.-S. 2008. Salamander-like development in a seymouriamorph revealed by palaeohistology. - Biology Letters 4: 411-414.

Sander, P. M. 1999. Life history of Tendaguru sauropods as inferred from long bone histology. - Mitteilungen Museum für Naturkunde Berlin, Geowissenschaftliche Reihe 2: 103-112.

Scheyer, T. M. 2007. Comparative bone histology of the turtle shell (carapace and plastron): implications for turtle systematics, functional morphology, and turtle origins. - Mathematisch-Naturwissenschaftliche Fakultät, University of Bonn, Bonn, Germany. PhD Thesis, 343 pp. [URN: http://nbn-resolving.de/urn:nbn:de:hbz:5N-12299; URL: http://hss.ulb.uni-bonn.de/diss_online/math_nat_fak/2007/ scheyer_torsten].

Scheyer, T. M. \& Sander, P. M. 2004. Histology of ankylosaur osteoderms: implications for systematics and function. - Journal of Vertebrate Paleontology 24: 874-893.

Scheyer, T. M. \& Sánchez-Villagra, M. R. 2007. Carapace bone histology in the giant pleurodiran turtle Stupendemys geographicus: phylogeny and function. - Acta Palaeontologica Polonica 52: $137-154$

Schneider, J. G. 1801. Historiae Amphibiorum naturalis et literariae. Fasciculus secundus continens Crocodilos, Scincos, Chamaesauras, Boas. Pseudoboas, Elapes, Angues. Amphisbaenas et Caecilias. Frommani, Jena.

Schürch, M., Kozel, R., Schotterer, U. \& Tripet, J.-P. 2003. Observation of isotopes in the water cycle - the Swiss National Network (NISOT). - Environmental Geology 45: 1-11.
Starck, J. M. \& Chinsamy, A. 2002. Bone microstructure and developmental plasticity in birds and other dinosaurs. - Journal of Morphology 254: 232-246.

Steele, K. W. \& Daniel, R. M. 1978. Fractionation of nitrogen isotopes by animals: a further complication to the use of variations in the natural abundance of $15 \mathrm{~N}$ for tracer studies. - Journal of Agricultural Science 90: 7-9.

Steyer, J.-S., Laurin, M., Castanet, J. \& Ricqlès, A. de 2004. First histological and skeletochronological data on temnospondyl growth: palaeoecological and palaeoclimatological implications. - Palaeogeography, Palaeoclimatology, Palaeoecology 206: 193-201.

Stoskopf, M. K., Barrick R. E. \& Showers, W. J. 2001. Oxygen isotope variability in bones of wild caught and constant temperature reared sub-adult American alligators. - Journal of Thermal Biology 26: $183-191$.

Spoetl, C. \& Vennemann, T. W. 2003. Continuous-flow IRMS analysis of carbonate minerals. - Rapid Communications in Mass Spectrometry 17: 1004-1006.

Straight, W. H., Barrick, R. E. \& Eberth, D. A. 2004. Reflections of surface water, seasonality and climate in stable oxygen isotopes from tyrannosaurid tooth enamel. - Palaeogeography, Palaeoclimatology, Palaeoecology 206: 239-256.

Suzuki, H. K. 1963. Studies on the osseous system of the slider turtle. Annals of the New York Academy of Sciences 109 (1): 351-410.

Tucker, A. D. 1997. Validation of skeletochronology to determine age of freshwater crocodiles (Crocodylus johnstoni). - Marine and Freshwater Research 48: 343-351.

Turmarkin-Deratzian, A. R. 2007. Fibrolamellar bone in wild adult Alligator mississippiensis. - Journal of Herpetology 41 (2): $341-$ 345.

Tütken, T. 2003. Die Bedeutung der Knochenfrühdiagenese für die Erhaltungsfähigkeit in vivo erworbener Element- und Isotopenzusammensetzungen in fossilen Knochen. PhD Thesis, Universität Tübingen, $330 \mathrm{pp}$.

Tütken, T., Pfretzschner, H.-U., Vennemann, T. W., Sun, G. \& Wang, Y. D. 2004. Paleobiology and Skeletochronology of Jurassic Dinosaurs: Implications from the histology and oxygen isotope compositions of bones. - Palaeogeography, Palaeoclimatology, Palaeoecology 206: 217-238.

Wink, C. S. \& Elsey, R. M. 1986. Changes in femoral morphology during egg-laying in Alligator mississippiensis. - Journal of Morphology 189: 183-188.

Zug, G. R., Wynn, A. H. \& Ruckdeschel, C. 1986. Age determination of loggerhead sea turtles, Caretta caretta, by incremental growth marks in the skeleton. - Smithonian contributions to Zoology 427: $1-34$. 